\section{A NEW ANTITUMOR ANTIBIOTIC, SPERGUALIN: ISOLATION AND ANTITUMOR ACTIVITY}

Sir :

In testing the activity of culture filtrates to inhibit focus formation of chicken fibroblasts by Rous sarcoma virus, an antibiotic produced by a bacillus isolated from a soil sample collected at Ohira-san, Tochigi Prefecture was thought to be worthy of further study, even though daily intraperitoneal injection $(0.25 \mathrm{ml})$ of its culture filtrate for 9 days caused death of mice and showed no effect in prolonging the survival period of mice bearing L-1210 leukemia. Since the culture filtrate inhibited the growth of B. subtilis and $S$. aureus, we extracted and purified the antibacterial activity. The antibiotic thus purified had a low toxicity and exhibited a marked effect against mouse L-1210 leukemia. The ratio of $50 \%$ inhibition concentration $(13 \mu \mathrm{g} / \mathrm{ml})$ against the growth of chicken fibroblasts to $50 \%$ inhibition concentration $(5.5 \mu \mathrm{g} / \mathrm{ml})$ against focus formation by Rous sarcoma virus was 2.3. On the basis of the structure which will be reported in the next paper $^{1)}$, this antibiotic was named spergualin. In this paper, we will report on the isolation and antitumor activity of spergualin.

The strain producing spergualin was numbered as BMG162-aF2 in the authors' Institute. The taxonomic study suggested that this strain was closely related to Bacillus laterosporus. Spergualin was produced, extracted and purified by the following processes. The strain BMG162$\mathrm{aF} 2$ was shake-cultured at $28^{\circ} \mathrm{C}$ in a medium containing $2.0 \%$ glycerol, $2.0 \%$ dextrin, $1.0 \%$ soy peptone (Bacto-soytone, Difco Laboratories), $0.3 \%$ yeast extract, $0.2 \%\left(\mathrm{NH}_{4}\right)_{2} \mathrm{SO}_{4}$ and $0.2 \%$ $\mathrm{CaCO}_{3}$ (adjusted to $\mathrm{pH}$ 7.4). After $3 \sim 4$ days culture, more than $100 \mu \mathrm{g} / \mathrm{ml}$ of spergualin was produced as shown by a cylinder plate assay using Bacillus subtilis PCI219 as the test organism. The antibiotic in the culture filtrate $(4,900$ $\mathrm{ml})$ was adsorbed on a column $(500 \mathrm{ml}$ in $5.2 \mathrm{~cm}$ diameter) of Amberlite IRC-50 $\left(70 \% \mathrm{Na}^{+}\right.$form $)$ and eluted with $1 \mathrm{~N} \mathrm{HCl}(2,000 \mathrm{ml})$. After neutralization of the eluate, the antibiotic was adsorbed on a column ( $400 \mathrm{ml}$ in $4.3 \mathrm{~cm}$ diameter) of CM-Sephadex C-25 and eluted with $0.3 \mathrm{M}$ $\mathrm{NaCl}$. The active eluate was concentrated to dryness and the residue was extracted with methanol $(5 \mathrm{ml})$. The methanol solution was passed through a column $(445 \mathrm{ml}$ in $2.6 \mathrm{~cm}$ diameter) of Sephadex LH-20 and the column was developed with methanol. The concentration of the active fractions gave pure spergualin trihydrochloride as a colorless hygroscopic powder $(460 \mathrm{mg})$. Physicochemical properties are described in the next paper ${ }^{1)}$.

Spergualin trihydrochloride is easily soluble in water and as shown in Table 1, in the usual agar dilution method on a nutrient agar plate, spergualin at $50 \sim 100 \mu \mathrm{g} / \mathrm{ml}$ inhibited the growth of Gram-positive and -negative bacteria except Serratia marcescens and $P_{S}$. aeruginosa. B. subtilis PCI219, S. aureus Smith, Sal. typhi T-63 and Pr. vulgaris OX19 were relatively sensitive to spergualin and their growth was inhibited at $6.25 \mu \mathrm{g} /$ $\mathrm{ml}$.

In a test where $10^{5} \mathrm{~L}-1210$ cells were intraperitoneally inoculated and spergualin dissolved in saline was injected daily from the following day

Table 1. The antimicrobial spectrum of spergualin trihydrochloride.

\begin{tabular}{|c|c|}
\hline Test organisms & $\begin{array}{c}\text { Minimum } \\
\text { inhibitory } \\
\text { concentrations } \\
(\mu \mathrm{g} / \mathrm{ml})\end{array}$ \\
\hline Staphylococcus aureus FDA209P & 50 \\
\hline Staphylococcus aureus Smith & 6.25 \\
\hline Micrococcus flavus FDA16 & 25 \\
\hline Micrococcus luteus PCI1001 & 50 \\
\hline Bacillus anthracis & 12.5 \\
\hline Bacillus subtilis PCI219 & 6.25 \\
\hline Bacillus subtilis NRRL B-558 & 25 \\
\hline Bacillus cereus ATCC10702 & 50 \\
\hline Corynebacterium bovis 1810 & 50 \\
\hline Escherichia coli $\mathrm{NIHJ}$ & 25 \\
\hline Escherichia coli $\mathrm{K}-12$ & 50 \\
\hline Escherichia coli K-12 ML1629 & 50 \\
\hline Escherichia coli K-12 ML1630 & 50 \\
\hline Klebsiella pneumoniae PCI602 & 50 \\
\hline Shigella dysenteriae JS11910 & 50 \\
\hline Shigella flexneri 4b JS11811 & 100 \\
\hline Shigella sonnei JS11746 & 50 \\
\hline Salmonella typhi $\mathrm{T}-63$ & 6.25 \\
\hline Salmonella enteritidis 1891 & 100 \\
\hline Proteus vulgaris $\mathrm{OX} 19$ & 6.25 \\
\hline Serratia marcescens & $>100$ \\
\hline Pseudomonas aeruginosa A3 & $>100$ \\
\hline Pseudomonas aeruginosa No. 12 & $>100$ \\
\hline
\end{tabular}


Table 2. Antitumor effect of spergualin on L-1210.

\begin{tabular}{c|c|c|c}
\hline $\begin{array}{c}\text { Schedule } \\
\text { (day) }\end{array}$ & $\begin{array}{c}\text { Dose } \\
\text { (mg/kg/day) }\end{array}$ & $\begin{array}{c}\mathrm{T} / \mathrm{C} \\
(\%)\end{array}$ & $\begin{array}{c}\text { Survivor } \\
(60 \text { days })\end{array}$ \\
\hline $1 \sim 9$ (i.p.-i.p.) & 50 & 295 & $0 / 8$ \\
& 25 & 334 & $0 / 8$ \\
& 12.5 & 586 & $4 / 8$ \\
& 6.25 & 732 & $8 / 8$ \\
& 3.13 & 441 & $3 / 8$ \\
& 1.56 & 301 & $1 / 8$ \\
& 0.78 & 107 & $0 / 4$ \\
\hline
\end{tabular}

Inoculum size: $10^{5}$ cells/mouse.

Table 3. Antitumor effect of spergualin on L-1210 solid type.

\begin{tabular}{c|c|c|c}
\hline $\begin{array}{c}\text { Schedule } \\
\text { (day) }\end{array}$ & $\begin{array}{c}\text { Dose } \\
(\mathrm{mg} / \mathrm{kg} / \text { day })\end{array}$ & $\begin{array}{c}\mathrm{T} / \mathrm{C} \\
(\%)\end{array}$ & $\begin{array}{c}\text { Survivor } \\
(30 \text { days })\end{array}$ \\
\hline $1 \sim 9$ (s.c.-i.p.) & 50 & $>309$ & $5 / 5$ \\
& 25 & $>309$ & $5 / 5$ \\
& 12.5 & $>309$ & $5 / 5$ \\
& 6.25 & $>240$ & $3 / 5$ \\
& 3.13 & 120 & $0 / 5$ \\
& 1.56 & 105 & $0 / 5$ \\
\hline
\end{tabular}

Inoculum size: $10^{5}$ cells/mouse.

the tumor cell inoculation, for 9 days, as shown in Table 2, $1.56 \sim 50 \mu \mathrm{g} / \mathrm{mg} /$ day prolonged the survival period of mice markedly. All mice treated with spergualin $6.25 \mathrm{mg} / \mathrm{kg} /$ day survived. The control mice died $7.5 \sim 8.5$ days after the tumor cell inoculation. The death of mice treated with 25 or $50 \mathrm{mg} / \mathrm{kg} /$ day was not due to the toxicity of spergualin. This was due to L-1210 leukemia, because the tumor cells grew as ascites before death. Mice died 7 33 days after the last injection of spergualin. As will be reported in an other paper, the inoculation of the tumor cells taken from mice treated with $50 \mu \mathrm{g} /$ mouse was significantly more resistant to spergualin treatment than the inoculation of the original L-1210 cells.

As shown in Table 3, spergualin showed a marked effect in prolonging the survival of mice to which $10^{5} \mathrm{~L}-1210$ cells were inoculated subcutaneously. All mice treated by intraperitoneal injection of spergualin $12.5,25,50 \mathrm{mg} / \mathrm{kg}$ daily survived. The treatment was started 1 day after the tumor cell inoculation and continued for 9 days. The mice without treatment died $8 \sim 10$ days after the inoculation. The mice which sur-
Table 4. Antitumor effect of spergualin on EL-4 mouse leukemia.

\begin{tabular}{c|c|c}
\hline $\begin{array}{c}\text { Schedule } \\
\text { (day) }\end{array}$ & $\begin{array}{c}\text { Dose } \\
\text { (mg/kg/day) }\end{array}$ & $\mathrm{T} / \mathrm{C}(\%)$ \\
\hline $1 \sim 9$ (i.p.-i.p.) & 5 & 193 \\
& 2.5 & 164 \\
& 1.25 & 159 \\
& 0.625 & 130 \\
& 0.313 & 131 \\
\hline
\end{tabular}

Inoculum size: $10^{5}$ cells/mouse.

vived were resistant to the second inoculation of L-1210 cells.

Spergualin also prolonged the survival period of mice to which $10^{5}$ cells of EL-4 mouse leukemia were inoculated as shown in Table 4.

Spergualin also prolonged the survival period of mice bearing Ehrlich carcinoma in the ascites form: $2 \times 10^{8}$ Ehrlich carcinoma cells were inoculated intraperitoneally to mice; spergualin was given intraperitoneally daily from 1 day after the inoculation for 9 days, and the percentage of the survival days to those of the control was $133 \%$ by $1.56 \mathrm{mg} / \mathrm{kg} /$ day, $188 \%$ by $3.13 \mathrm{mg} / \mathrm{kg} /$ day, $236 \%$ by $6.25 \mathrm{mg} / \mathrm{kg}, 170 \%$ by $12.5 \mathrm{mg} / \mathrm{kg}$. Higher doses such as 25 or $50 \mathrm{mg} / \mathrm{kg} /$ day shortened the survival period ( $72 \%$ by $25 \mathrm{mg} / \mathrm{kg} /$ day, $54 \%$ by $50 \mathrm{mg} / \mathrm{kg} / \mathrm{day}$ ). In this case, ascites did not increase and the cause of the death was not certain.

In experiments performed by a procedure similar to the one to test the effect against Ehrlich carcinoma, spergualin prolonged the survival period of mice bearing sarcoma $180: 220 \%$ by $1.56 \mathrm{mg} / \mathrm{kg} /$ day, $243 \%$ by $3.13 \mathrm{mg} / \mathrm{kg} /$ day, $181 \%$ by $6.25 \mathrm{mg} / \mathrm{kg} /$ day, $279 \%$ by $12.5 \mathrm{mg} / \mathrm{kg} /$ day. High doses such as $50 \mathrm{mg} / \mathrm{kg} /$ day or $25 \mathrm{mg} / \mathrm{kg} /$ day shortened the survival period $(53 \%$ by $50 \mathrm{mg} / \mathrm{kg} /$ day; $69 \%$ by $25 \mathrm{mg} / \mathrm{kg} /$ day).

Spergualin has low toxicity: intravenous injection of $80 \mathrm{mg} / \mathrm{kg}$ did not cause the death of mice but the $\mathbf{L D}_{50}$ markedly fluctuated depending on the injection speed. The $\mathrm{LD}_{50}$ by intraperitoneal injection was about $150 \mathrm{mg} / \mathrm{kg}$. It was found that spergualin seems to have no cumulative toxicity.

\section{Acknowledgments}

This work was partly supported by a Contract No. NO1-CM-57009 with the Division of Cancer Treat- 
ment, National Cancer Institute, U. S. A., a Grantin-Aid for Cancer Research from the Ministry of Education, Science and Culture, Japan and from the Ministry of Health and Welfare, Japan.

TOMIO TAKEUCHI Hironobu IINUMA Setsuko Kunimoto TORU Masuda MASAAKI ISHIZUKA Mieko TAKeUCHI Masa Hamada Hiroshi NaganaWA SHINICHI KONDO HaMaO UMEZAWA
Institute of Microbial Chemistry 14-23 Kamiosaki 3-Chome, Shinagawa-ku, Tokyo 141, Japan

(Received September 30, 1981)

\section{Reference}

1) Umezawa, H.; S. Kondo, H. Innuma, S. Kunimoto, Y. Ikeda, H. Iwasawa, D. Ikeda \& T. TAKEUCHI: Structure of an antitumor antibiotic, spergualin. J. Antibiotics 34: 1622 1624, 1981 